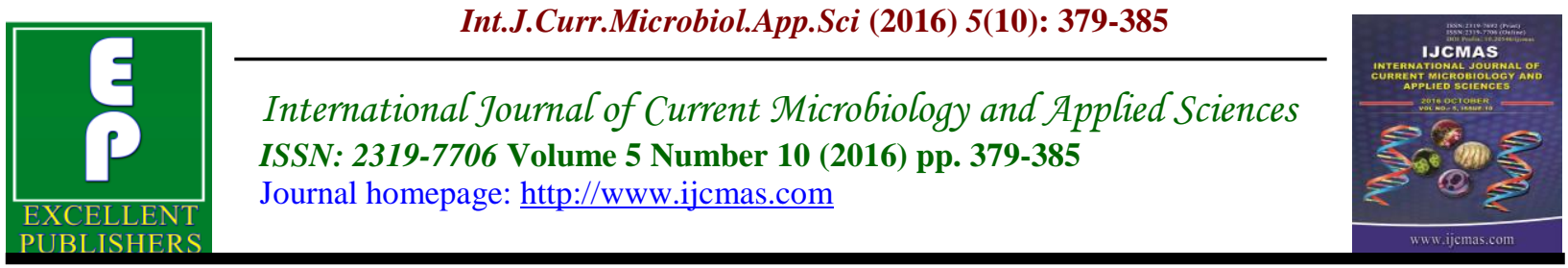

Original Research Article

http://dx.doi.org/10.20546/ijcmas.2016.510.043

\title{
Potential of Halophilic Bacteria for Extracellular Enzymes
}

\author{
K.D. Kamble* \\ Department of Microbiology, Sant Gadge Baba Amravati University, \\ Amravati, Maharashtra, India \\ *Corresponding author
}

\section{Keywords}

Halophiles, bacteria, enzymes, efficiency L-asparaginase

Article Info

Accepted:

14 September 2016 Available Online: 10 October 2016
A B S T R A C T

Although protease, amylase and lipase are frequently studied; in the list Lasparaginase also finds position. Halophilic enzymes are currently preferred because these remains active at wide range of $\mathrm{pH}$ and temperature and also the yield of purified functional enzymes is high. Having studied around 29 bacteria for DNA degrading abilities; as extended part of the study these bacteria are undertaken to determine their potential for protease, amylase, lipase and Lasparaginase productions. The study included members of genera Providencia, Rheinheimera, Halomonas, Alishewanella, Serratia, Marinobacter, Marinospirillum, Bacillus, Exiguobacterium and Vibrio species. The enzymatic activities were observed in terms of detectable zones of hydrolysis which were measured. The zones of hydrolysis appeared after $24 \mathrm{~h}$ and were at its maximum towards $48 \mathrm{~h}$. The results revealed enzyme activities largely varied among genus and within genus also. Amylase was efficiently produced by Bacillus cereus (DN3), Vibrio species (DN25), Marinobacter species (DN16) whereas excellent protease activity was exhibited by Bacillus cereus (DN3), Bacillus thuringiensis (DN2) and Vibrio Sp (DN25). Exiguobacterium (SK1 and SK2) was found to be the most efficient lipase producing bacteria followed by Providencia rettgeri (DN1) and Bacillus thuringiensis (DN2). The therapeutic enzyme L-asparaginase was produced only by two bacteria i.e. Pseudomonas (DN13) and Halomonas (DN19). Looking at industrial market of the enzymes; it is suggested that these bacteria would be promising sources of stable and robust enzymes.

\section{Introduction}

Meteorite impact craters frequently strikes on surface of moon, whereas very few are experienced by earth of which Lonar Lake impact crater situated in Buldhana district, Maharashtra State, India is one. The crater is aged approximately 50,000 years covering an area of $1.9 \mathrm{~km}$ and depth of $135 \mathrm{~m}$ (Vijayan et al., 2012; Antony et al., 2012).
However the lake is experiencing both topological modifications and physicochemical changes as the diameter and salinity is changing because of infilling of the lake by people's activity as well as by seasonal monsoon.

The lake is of an immense field of interest harboring potential bacterial metabolites and 
enzymes of industrial and medicinal use. Bacterial culture dependent studies from this lake were initiated by Joshi et al., which stated predominance of Firmicutes over Proteobacteria (Joshi et al., 2008). This fact was also supported by Deshmukh et al., wherein seven Firmicutes and three Proteobacteria were reported (Deshmukh et al., 2013). In recent years presence of haloalkaliphilic methanogenic bacteria was revealed in this lake including a novel species, namely Methylophaga lonarensis (Antony et al., 2012). Sharma et al., (2016) also isolated a novel species from Lonar lake i.e. Streptomyces lonarsensis. Bacterium Bacillus lonarensis is also among the novel species reported recently (Reddy et al., 2015). Culture independent approaches reports Firmicutes 34\% followed by Proteobacteria (29.5\%), Actinobacteria (6.8\%), Deinococcus-thermus (4.5\%), Cytophages-flavobacterium-bacteroidetes (13.3\%), Planctomycetes (6.8\%), Cyanobacteria (4.5\%) and Spirochetes $(2.27 \%)$ of which $80 \%$ belonged to cultivable bacteria (Wani et al., 2006). Metagenome approaches also showed presence of Coxiella burnetii (17\%), Fibrobacter intestinalis (12\%), Candidatus Cloacamonas acidaminovorans (11\%) and archaebacteria like Methanosaeta harundinacea (35\%), Methanoculleus chikugoensis (12\%) and Methanolinea tarda (11\%) were reported to be dominant (Dudhagara $e t$ al., 2015).

Phylogenic analyses were also carried to study temporal diversity after beginning and well before beginning of monsoon. Seasonal variation in bacterial flora before and after monsoon showed a majority of Cyanobacteria (>80\%). Fusibacter and Tindallia magadiensis were found in postmonsoon samples only, whereas species of Planococcus rifietensis, Bordetella hinzii and Methylobacterium variabile were reported in pre-monsoon samples. Presence of phototrophic bacteria in post monsoon samples was also reported by Surakasi et al., (2010).

Halophilic enzymes are known to be active at a wide range of $\mathrm{pH}$ and temperature; preferably those also resist changes in purification steps. The enzymes like amylase, lipase, caseinase and cellulase were studied by Joshi et al., (2008). Arsenic oxidizing and arsenic reducing bacteria have been recently reported from Lonar Lake (Bagade et al., 2016). Alkaline enzymes like protease have been optimized by Rathod and Pathak (2016). Lipase enzyme from Lysinibacillus mangiferihumi is characterized by Tambekar et al., (2016). Cyclodextrin glycosyl transferase is one more important enzyme to mention that convert starch and related glycans into cyclodextrins (Vinod and More, 2016). In order to find out few more alternatives to existing enzymes it would be important to report potent bacteria from alkaline Lonar Lake which is focus of present work.

\section{Materials and Methods}

\section{Bacteria under study}

Samples were collected from Lonar Lake in winter season. Alkaliphilic bacteria from this Lake were previously studied for DNA degradation (unpublished data). Having studied around 29 bacteria for DNA degrading abilities these were further studied for production of amylase, protease, lipase and L-asparaginase.

\section{Amylase production}

The amylase production was detected on a media containing $1 \%$ soluble starch. Plates were incubated for $24 \mathrm{hr}$ and halos were measured by conventional method of iodine addition (Khanderparker et al., 2011). 


\section{Protease production}

A media containing casein was employed for protease production. The zones of hydrolysis were measured after overnight incubation (Gessesse and Gashe, 1997).

\section{Lipase Production}

One percent egg yolk was added to the nutrient media and zone of clearance were noted by spot inoculation after $24 \mathrm{hr}$ incubation (Walavalkar \& Bapat, 2002).

\section{L-asparaginase production}

A mineral base agar supplemented with glucose as carbon source and L-asparaginase as nitrogen source plus phenol red as indicator system was used for this purpose. After breakdown of L-asparagine to ammonia the color of medium changes from yellow to pink. Plates were incubated for two days at $37^{0} \mathrm{C}$ (Prakasham et al., 2007).

\section{Results and Discussions}

The zone of starch hydrolysis was maximum i.e. $20 \mathrm{~mm}$ in case of Bacillus cereus (DN3) followed by Vibrio species (DN25), Marinobacter species (DN16) with hydrolysis zones of $18 \mathrm{~mm}$ and $15 \mathrm{~mm}$ respectively (Fig1B).

The proteolytic zone of Bacillus cereus (DN3) was maximum i.e. $34 \mathrm{~mm}$ and that of Bacillus thuringiensis (DN2) and Vibrio Sp (DN25) was 28 and $24 \mathrm{~mm}$ respectively (Fig1C). Excellent lipolytic activity was observed in case of Exiguobacterium sp (SK1 and SK2) with similar zone of hydrolysis i.e. $30 \mathrm{~mm}$ each whereas that of Providencia rettgeri (DN4) and Bacillus thuringiensis (DN2) was $25 \mathrm{~mm}$ each (Fig1A). The L-asparaginase activity was observed on the basis of pink coloration around the colony because of formation of ammonia due to L- asparagine break down. The therapeutic enzyme L-asparaginase was produced only by two bacteria i.e. Pseudomonas (DN13) and Halomonas (DN19) (Fig1D). Some of the species utilized L-asparagine but there was no detectable zone of hydrolysis. This might suggest the substrate is absorbed and utilized within the cell indicating the enzyme Lasparaginase is produced intracellularly. Many cultures could not utilize L-asparagine (Table1).

Members of Bacillus and Pseudomonas were frequently reported from Lonar Lake. In recent years protease enzyme is purified from species of Bacillus from Lonar Lake (Pathak and Deshmukh, 2012). We isolated species of Vibrio viz. Vibrio natriengens which is one of the fastest growing bacterium and is also a model organism for study of promoter. The bacterium is also an efficient producer of poly-betahydroxybutyrate (PHB) studied from marine sediments leading to faster production of PHB within short period of time (Chien, 2007). Species of Marinobacter, Exiguobacterium, Alishewanella and Rheinheimera and Marinospirillum are studied for various enzyme productions which are among the rare flora present in this lake. The spiral shaped gamma proteobacteria were designated as Marinospirillum by Satomi et al., (1998) which previously were close to Oceanospirillum. Sufficient enzymatic data of Marinospirillum is unavailable especially with regards to purification. 
Table.1 Comparative study of enzymes represented by zone of hydrolysis

\begin{tabular}{|c|c|c|c|c|c|c|}
\hline \multirow{2}{*}{$\begin{array}{c}\text { Culture } \\
\text { Code }\end{array}$} & \multirow{2}{*}{ Name of Bacterium } & \multirow{2}{*}{$\begin{array}{c}\text { Accession } \\
\text { Number }\end{array}$} & \multicolumn{4}{|c|}{ Zone of enzymatic hydrolysis } \\
\hline & & & Amylase & Protease & Lipase & L-asparginase \\
\hline DN1 & Providencia sp. & JX298813 & - & - & - & - \\
\hline DN2 & Bacillus thuringiensis & JX298814 & 14 & 28 & 25 & - \\
\hline DN3 & Bacillus cereus & JX298815 & 20 & 34 & - & - \\
\hline DN4 & Providencia rettgeri & JX298816 & 13 & 27 & 25 & - \\
\hline DN5 & Vibrio metschnikovii & JX298817 & - & - & - & - \\
\hline DN6 & Halomonas venusta & JX298818 & - & - & - & - \\
\hline DN7 & Alishewanella Sp. & JX298819 & - & 18 & - & - \\
\hline DN8 & Pseudomonas putida & JX298820 & - & - & - & - \\
\hline DN9 & Alishewanella Sp. & JX298821 & - & 19 & 24 & - \\
\hline DN12 & Serratia rubidaea & JX298822 & - & - & - & - \\
\hline DN13 & Pseudomonas Sp. & JX298823 & - & - & - & 18 \\
\hline DN15 & Alishewanella Sp. & JX298838 & - & 18 & - & - \\
\hline DN16 & Marinobacter Sp. & JX298824 & 15 & 13 & - & - \\
\hline DN19 & Halomonas Sp. & JX298825 & - & 8 & 18 & 16 \\
\hline DN20 & Halomonas campisalis & JX298826 & - & - & - & - \\
\hline DN21 & Marinospirillum $\mathrm{Sp}$ & JX298827 & 11 & - & - & - \\
\hline DN22 & Marinospirillum Sp. & JX298828 & - & - & - & - \\
\hline DN24 & Rheinheimera chironomi & JX298829 & - & 7 & - & - \\
\hline DN25 & Vibrio Sp. & JX298830 & 18 & 24 & 25 & - \\
\hline DN26 & Vibrio natriegens & JX298831 & - & - & - & - \\
\hline DN27 & Vibrio metschnikovii & JX298832 & - & - & - & - \\
\hline DN28 & Vibrio metschnikovii & JX298833 & - & - & - & - \\
\hline DN29 & Vibrio natriegens & JX298834 & - & 14 & 11 & - \\
\hline DN30 & Vibrio natriegens & JX298835 & - & - & - & - \\
\hline DT1 & Serratia marcescens & KC130919 & - & 21 & 18 & - \\
\hline DT2 & Serratia marcescens & KC130920 & - & 21 & 18 & - \\
\hline DT3 & Staphylococcus sp. & KC130921 & - & - & - & - \\
\hline SK2 & Exiguobacterium sp. & KC130922 & 12 & 23 & 30 & - \\
\hline SK3 & Exiguobacterium sp. & KC130923 & 12 & 23 & 30 & - \\
\hline
\end{tabular}


Fig.1 Representative media plates A] Lipase B] Amylase C] Protease D] L-asparaginase
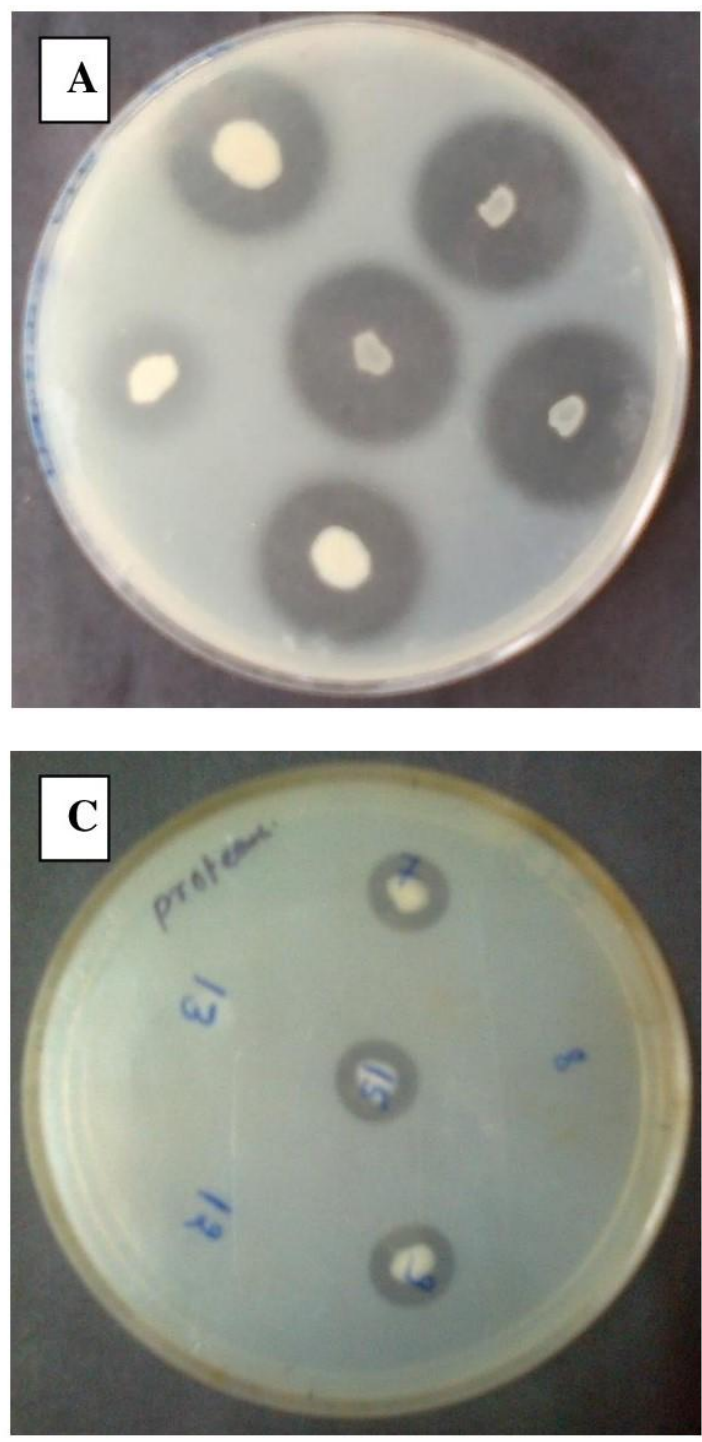

Bacteria of the genus Exiguobacterium were found both in psychrophilic and thermophilic environments. The genus was well studied for nucleolytic enzymes by Vishnivetskaya et al., (2009). The species reported in this study are promising sources of industrial and therapeutic enzymes. During study it was noted that the enzymatic activities largely varied within the genera and also within species.

In conclusion, as the industrial and therapeutic applications of enzymes are increasing there is continuous need to search
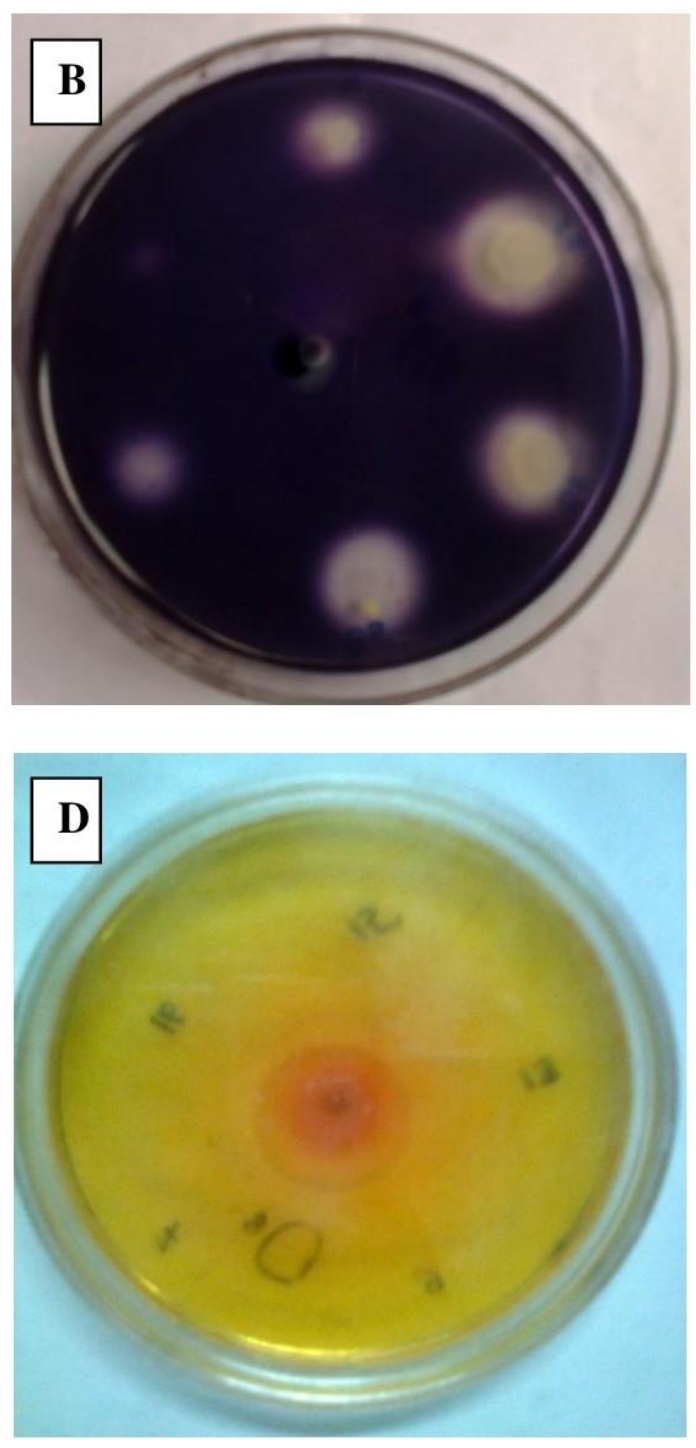

efficient bacteria that has the ability to produce the enzyme extracellularly. The bacteria reported in this study would be promising sources of these enzymes. The most promising bacterium in the study was Bacillus cereus (DN3) which could synthesize both amylase and protease efficiently. Exiguobacterium sp (SK1 and SK2) is also a candidate for lipase production. Pseudomonas (DN13) and Halomonas (DN19) have not been previously studied for L-asparaginase production from this lake. 


\section{References}

Antony, C.P., Doronina, N.V., Boden, R., Trotsenko, Y.A., Shouche, Y.S. and Murrell, J.C. 2012. Methylophaga lonarensis, A Novel Moderately Haloalkaliphilic Methylotroph Isolated From the Soda Lake Sediments of A Meteorite Impact Crater. Int. J. Syst. Evol. Microbiol., vol. 62, pp. 16131618.

Bagade, A.V., Bachate, S.P., Dholakia, B.B., Giri, A.P., \& Kodam, K.M. 2016. Characterization of Roseomonas and Nocardioides spp. for arsenic transformation. $J$. Hazardous Materials, doi:10.1016/j.jhazmat.2016.07.062

Chien, C.C., Chen, C.C., Choi, M.H., Kung, S.S. and Wei, Y.H., Production of Poly-beta-hydroxybutyrate (PHB) by Vibrio spp. Isolated from Marine Environment. J. Biotechnol., vol. 132, pp. 259-263.

Deshmukh, K.B., Pathak, A.P. and Karuppayil, M.S. 2011. Bacterial diversity of lonar soda lake of India. Ind. J. Microbiol., vol. 51, pp. 107111.

Dudhagara, P., Ghelani, A., Patel, R., Chaudhari, R., \& Bhatt, S. 2015. Bacterial tag encoded FLX titanium amplicon pyrosequencing (bTEFAP) based assessment of prokaryotic diversity in metagenome of Lonar soda lake, India. Genomics data, 4: 8-11.

Gessesse, A., Gashe, B.A. 1997. Production of alkaline protease by an alkaliphilic bacteria isolated from an alkaline soda lake. Biotechnol. Lett., 19(5): 479-481.

Joshi, A.A., Kanekar, P.P., Kelkar, A.S., Shouche, Y.S., Vani, A.A., Borgave, S.B. and Sarnaik, S.S. 2008. Cultivable Bacterial Diversity of Alkaline Lonar Lake, India. Microb. Ecol., vol. 55, pp. 163-172.
Khanderparker, R., Verna, P., Meena, R.M. and Deobagkar, D.D. 2011. Phylogenetic Diversity of Carbohydrate Degrading Culturable Bacteria from Mandovi and Zuari Estuaries, Goa, West Coast of India. Estuarine Coastal and Shelf Sci., vol. 95, pp. 359-366.

Pathak, A.P. and Deshmukh, K.B. 2012. Alkaline Protease Production, Extraction and Characterization from Alkaliphilic Bacillus licheniformis KBDL4: A Lonar Soda Lake Isolate. Ind. J. Expt. Biol., vol. 50, pp. 569576.

Prakasham, R.S., Rao, C.S., Rao, R.S., Lakshmi, G.S. and Sarma, P.N. 2007. L-asparaginase production by isolated Staphylococcus sp.-6A: design of experiment considering interaction effect for process parameter optimization. J. Appl. Microbiol., vol. 102, pp. 1382-1391.

Rathod, M.G., Pathak, A.P. 2016. Optimized production, characterization and application of alkaline proteases from taxonomically assessed microbial isolates from Lonar soda lake, India. Biocatalysis and Agri. Biotechnol., 7: 164- 173

Reddy, S.V., Thirumala, M., Farooq, M., Sasikala, C., \& Ramana, C.V. 2015. Bacillus lonarensis sp. nov., an alkalitolerant bacterium isolated from a soda lake. Arch. Microbiol., 197(1): 27-34.

Sahay, H., Mahfooz, S., Singh, A.K., Singh, S., Kaushik, R., Saxena, A.K. and Arora, D.K. 2012. Exploration and Characterization of Agriculturally and Industrially Important Haloalkaliphilic Bacteria from Environmental Samples of Hypersaline Sambhar Lake, India. World J. Microbiol. Biotechnol., vol. 28, pp. 3207-3217. 
Satomi, M., Kimura, B., Hayashi, M., Okuzumi, M. and Fujii, T. 1998. Marinospirillum gen. nov., with Descriptions of Marinospirillum megaterium sp. nov., Isolated from Kusaya Gravym and Transfer of Oceanospirillium minutulum to Marinospirillum minutulum copb. nov. Int. J. Syst. Bacteriol., vol. 48, pp. 1341-1348.

Sharma, T.K., Mawlankar, R., Sonalkar, V.V., Shinde, V.K., Zhan, J., Li, W.J., Kumar, L.S. 2016. Streptomyces lonarensis sp. nov., isolated from Lonar Lake, a meteorite salt water lake in India. Antonie van Leeuwenhoek, 109(2): 225-235.

Surakasi, V.P., Antony, C.P., Sharma, S., Patole, M.S. \& Shouche, Y.S. 2010. Temporal bacterial diversity and detection of putative methanotrophs in surface mats of Lonar Crater Lake. $J$. Basic Microbiol., 50: 465-474.

Tambekar, D.H., Tambekar, S.D., Jadhav, A.S., \& Sharma, N.H. 2016. Thermophilic Lipase from Lysinibacillus mangiferihumi: Screening and Partial Characterization. Indian J. Appl. Res., 6(6): 432-434.
Vijayan, S., Vani, K. and Sanjeevi, S. 2012. Topographical Analysis of Lonar Crater Using Cartosat-1 DEM. J. Ind. Soc. Remote Sens., DOI 10.1007/s12524-012-0216-5

Vinod, A.S., \& More, S.M. 2016. Purification and Characterization of a Novel CGTase from Alkaliphilic Bacillus flexus Isolated from Lonar lake, India. Int. J. Curr. Microbiol. App. Sci., 5(7): 164-170.

Vishnivetskaya, T.A., Kathariou, S. and Tiedje, J.M. 2009. The Exiguobacterium genus: Biodiversity and Biogeography. Extremophiles, vol. 13, pp. 541-555.

Walavalkar, G.S., Bapat, M.M. 2002. Staphylococcus warneri BW 94-A new source of lipase. Indian J. Experimental Biol., 40(11): 12801284.

Wani, A.A., Surakasi, V.P., Siddharth, J., Raghavan, R.G., Patole, M.S., Ranade, D. and Shouche, Y.S. 2006. Molecular Analyses of Microbial Diversity Associated with the Lonar Soda Lake in India: an Impact Crater in a Basalt Area. Res. Microbiol., 157: pp. 928937.

\section{How to cite this article:}

Kamble, K.D. 2016. Potential of Halophilic Bacteria for Extracellular Enzymes. Int.J.Curr.Microbiol.App.Sci. 5(10): 379-385. doi: http://dx.doi.org/10.20546/ijcmas.2016.510.043 